\title{
Normal values of biochemical parameters in serum of New Zealand White Rabbits
}

\section{Yeni Zelanda Beyaz Tavșanlarında serum biyokimyasal parametrelerinin normal değerleri}

\author{
Özcan ÖZKAN', Selçuk PEKKAYA²
}

\section{ABSTRACT}

Objective: Laboratory animals, which are an organ complex, are used as model for human in biomedical studies. For this reason, information about the normal physiological values of laboratory animals provide important information on their health status. In this study, it is aimed to determine the serum normal biochemical values of New Zealand rabbits.

Methods: Blood was taken from the ears of 93 rabbits. Biochemical tests were performed on serum samples. For analyses, commercial diagnostic kits were used for determination of biochemical parameters. Statistically, the difference between the mean values of the variables according to male and female rabbit was analyzed by independent sample t-test.

Results: Albumin, protein, CK (creatin kinase) and LDH (lactade dehydrogenase) $(p<0.05)$ values were found statistically significant between male and female rabbits. On the other hand, creatinine, cholesterol and Mg values $(p<0.05)$ increased significantly in female rabbits.

Conclusion: Biochemical tests should be conducted at regular intervals to assess the health status of animals. Since many variables are linked, the animals

\section{ÖZET}

Amaç: Bir organ kompleksi olan laboratuvar hayvanları biyomedikal çalıșmalarda insanlar için model olarak kullanılmaktadır. Bu nedenle, laboratuvar hayvanlarının normal fizyolojik değerleri, sağıık durumlarıyla ilgili önemli bilgiler sağlar. Bu çalıșmada da Yeni Zelanda tavşanlarının serum normal biyokimyasal değerlerinin belirlenmesi amaçlanmıștır.

Yöntem: Toplam $93\left(600^{x} ; 33\right.$ ㅇ $)$ tavșanın kulaklarından kan alındı. Serum örneklerinde biyokimyasal testler yapıldı. Analizler için biyokimyasal parametrelerin belirlenmesinde ticari teșhis kitleri kullanıldı. İstatistiksel olarak, erkek ve diși tavșana göre değișkenlerin ortalama değerleri arasındaki fark bağımsız sample t-testi ile analiz edildi.

Bulgular: Erkek tavșanların albümin, protein, CK (keratin kinaz) ve LDH (laktat dehidrogenaz) $(p<0.05)$ değerleri diși tavșanlara göre istatistiksel olarak anlamlı bulunmuștur. Öte yandan diși tavșanlarda kreatinin, kolesterol ve $M g$ değerleri $(p<0.05)$ önemli derecede yüksek bulunmuștur.

Sonuç: Hayvanların sağlık durumlarının değerlendirilmesi için düzenli aralıklarla biyokimyasal testler yapılmalıdır. Birçok değișkene bağıı olduğundan

${ }^{\prime}$ Çankırı Karatekin University, Faculty of Science, Department of Biology, Çankırı

${ }^{2}$ Ankara University, Faculty of Veterinary, Medicine Department of Microbiology, Ankara

İletişim / Corresponding Author : Özcan ÖZKAN

Çankırı Karatekin Üniversitesi Fen Fakültesi Biyoloji Bölümü 18000 Çankırı - Türkiye

Tel : +905396361071 E-posta/E-mail : ozcanozkan@karatekin.edu.tr

Geliș Tarihi / Received : 21.02.2018

Kabul Tarihi / Accepted : 26.06.2018

DOI ID : 10.5505/TurkHijven.2018.53254

Özkan Ö, Pekkaya S. Normal values of biochemical parameters in serum of New Zealand White Rabbits.

Turk Hij Den Biyol Derg, 2019; 76(2): 157-162 
used in the research should be based on the values of the control group on the same conditions.

Key Words: Rabbit, New Zealand white, serum, biochemical parameters araștırmalarda kullanılan hayvanlarda aynı koșullardaki kontrol grubunun değerleri temel alınmalıdır.

Anahtar Kelimeler: Tavșan, Yeni Zelanda beyaz, serum, biyokimyasal parametreler

\section{INTRODUCTION}

In currently, laboratory animals are still Material

considered to be necessary, when there are no alternatives, laboratory animals are used widely in biomedical sciences and the production of antibodies and vaccine and sera quality control tests (1-3). Therefore in vitro models that can completely mimic the complexity of the human organism are still not available today. The New Zealand white rabbit is one of the most popular laboratory animals in the world because of their relatively large size and docile. In addition, using rabbits as experimental models, there are some advantages such as easy to handle and observe, large number of individuals, and short biologic cycles, ability to adapt to environmental conditions, and genetic standardization. The animal is widely used as a model for in vivo studies including in biomedical studies, surgery, atherosclerosis research, antibody production, pyrogen tests and eye studies (4-8).

At this stage, physiological biochemical values in serum provide valuable information on objective evaluation of health status in rabbits, in order to detect health failures or for monitoring stress factors already at a preclinical phase (9-12). In rabbit breeding, changes in biochemical parameters can be used as indicators of welfare status. Reference values of biochemical parameters provide important information for clinicians during diseases. The aim of the present study was to determine the normal biochemical values in serum in both male and female New Zealand white rabbits.

\section{MATERIAL and METHOD}

Animals

In total, 93 rabbits $\left(9: 33, \sigma^{x}: 60\right)$ were used for serum biochemical analysis. The samples were taken from weighing 1.5 to $3 \mathrm{~kg}$ New Zealand white rabbits. The animals were housed in single rabbit cages in suitable environmental conditions $\left(22 \pm 2^{\circ} \mathrm{C}, 12\right.$-h light, and dark cycles). The animals were given ad libitum commercial pelleted food and drinking tap water.

\section{Method}

\section{Collection of Blood Samples}

The blood samples were collected by marginal ear vein puncture. The sample for biochemical analysis was collected in sterile plain tubes. Blood samples were centrifuged at $3000 \mathrm{rpm}$ for $10 \mathrm{~min}$. And serums were kept at $-20^{\circ} \mathrm{C}$ until use.

\section{Analysis of Biochemical Parameters}

For biochemical analyses, commercial diagnostic kits (Quimica Clinica Aplicada) were used for determination of biochemical parameters such as glucose, total proteins, albumin, alanine aminotransferase (ALT), aspartate amino transferase (AST), alkaline phosphatase (ALP), gamma-glutamyl transferase (GGT), lactate dehydrogenase (LDH), alkaline phosphatase (ALP), blood urea nitrogen (BUN), uric acid, creatinine, creatin kinase (CK), triglyceride, cholesterol, total bilirubin (TB), calcium $(\mathrm{Ca})$, phosphorus $(\mathrm{P})$, magnesium $(\mathrm{Mg})$ were measured on full automated biochemistry analyzer (BT 3000 plus). 


\section{Statistical analysis}

The descriptive statistics for the variables are given by mean, standard error of means, and standard deviation. The difference between the mean values of the variables according to in males and females were analyzed by independent sample $t$ test. In all statistical analyzes, alpha $=0,05(p<0,05)$ was taken as significant. Statistical analyzes were performed in SPSS V.22 statistical package program.

\section{RESULTS}

Blood samples were taken from 93 rabbits $(9: 33$, $\left.0^{x}: 60\right)$. According to gender, the all biochemical parameters were presented in Table 1 including arithmetic means and standard error of means. And statistical diference results, between male and female animals also are shown in Tables 1.

In male serum biochemical parameters; albümin, protein, CK, and LDH $(p<0.05)$ values increased significantly when compared with the female biochemical values. However, creatinine, cholesterol and $M g$ values $(p<0.05)$ increased significantly in female rabbits (Table 1). There was no statistically significant difference for other serum biochemical parameters between male and female animals.

Table 1. Normal biochemical values in New Zealand rabbit serum

\begin{tabular}{|c|c|c|c|c|}
\hline \multirow{2}{*}{ PARAMETERS } & \multicolumn{2}{|c|}{ MALE $(\mathrm{n}=60)$} & \multicolumn{2}{|c|}{ FEMALE $(n=33)$} \\
\hline & Mean & SEM & Mean & SEM \\
\hline Albumin (g/L) & 48.66 & 0.77 & 44.93 & 0.56 \\
\hline AST (U/L) & 33.27 & 2.78 & 32.82 & 2.81 \\
\hline Protein $(\mathrm{g} / \mathrm{L})$ & 71.37 & 0.83 & 68.48 & 1.15 \\
\hline $\operatorname{ALP}(U / L)$ & $98.98^{*}$ & 10.79 & 111.55 & 17.05 \\
\hline ALT (U/L) & 28.18 & 3.32 & 27.85 & 3.05 \\
\hline GGT (U/L) & 9.750 & 0.35 & 10.47 & 1.16 \\
\hline BUN (mg/dL) & 41.28 & 1.74 & 37.52 & 1.54 \\
\hline Creatinine $(\mathrm{mg} / \mathrm{dL})$ & $1.00^{*}$ & 0.05 & 2.23 & 0.52 \\
\hline $\mathrm{Ca}(\mathrm{mg} / \mathrm{dL})$ & 13.19 & 0.07 & 11.59 & 0.80 \\
\hline CK (U/L) & $570.12^{*}$ & 48.21 & 413.97 & 35.87 \\
\hline LDH (U/L) & $385.20^{*}$ & 21.84 & 304.55 & 22.25 \\
\hline TB (mg/dL) & 0.28 & 0.02 & 0.22 & 0.02 \\
\hline$M g(\mathrm{mg} / \mathrm{dL})$ & 2.43 & 0.12 & 2.91 & 0.11 \\
\hline$P(\mathrm{mg} / \mathrm{dL})$ & $4.68^{*}$ & 0.14 & 4.57 & 0.28 \\
\hline Cholesterol (mmol/L) & $37.35^{*}$ & 2.21 & 59.61 & 5.094 \\
\hline Uric Acid (mg/dL) & 0.48 & 0.04 & 0.48 & 0.05 \\
\hline Triglyceride (mg/dL) & 91.67 & 6.77 & 105.76 & 10.43 \\
\hline Glucose (mg/dL) & 116.35 & 4.29 & 129.00 & 7.91 \\
\hline
\end{tabular}

${ }^{*}$ : statistical difference is indicated as $p<0.05$

SEM : Standard error of means 


\section{DISCUSSION}

Numerous studies reported that blood biochemistry parameters can be shown differences in the animal as well as laboratory animals. There are some factors related to the animals (age, species, strain, and sex), environmental conditions, bleeding, sampling procedures, and analysis method (5, 11-13). In addition, the factors can affect serum biochemical values. In our present study was carried out to determine the normal or reference biochemical values in serum samples in the rabbits.

Serum biochemical analysis can play an important role in accurate diagnosis of renal diseases, therefore, some biochemical markers such as creatinine, urea, uric acid and electrolytes levels in serum give knowledge for kidney function (9). In our study, rabbit serum creatinine and BUN levels were determined higher than previous studies (7, 11, 14, 16). There was a statistically significant difference in the serum biochemical parameters between male and female animals. The previous studies were reported differences in glucose levels that serum glucose levels in live animals can be affected because of different factors such as blood collection procedure environmental conditions and stress. In this parallel, the glucose level results of our study were similar to those of the previous studies $(11,15,16)$, while the glucose result was lower than another study (17). Total protein level results were similar to our results $(11,15,16)$, and higher than another study (14), while the parameters were reported parallel with our results.

Serum biochemical parameters also an important indicator for valuable information about functions of the liver, the kidney, and heart. ALT is an enzyme specific to liver and is a symptom of liver damage. But in rabbits the heart rate contains a high amount of
ALT. Therefore also it used as a marker of damage to the heart muscle. AST, on the other hand, is a unique enzyme of the liver, heart, skeletal muscle, kidney and pancreas. According to a study conducted in rabbits, decapitation, aortic incision, false high AST levels in the blood taken from the heart using a direct blood collection methods were determined. The reason for this false positivity is that the skeletal muscle is damaged in every way and the compression of the skeletal muscles during the fixation of the animal is reportedly the result of destruction in the resultant muscles. ALP activity increases in humans in rats and in many other species during pregnancy, whereas in rabbits there is a decline (18-21). When our results of biochemical parameters were compared with some previous biochemical studies of New Zealand Rabbits, serum ALP, AST (11, 15, 17), ALP (16) and GGT (14, 15) activities were lower, whereas, the serum GGT (11), ALT (14), and AST (16) activities were found higher. Likewise, the GGT parameters (17) was found similar value.

In normal laboratory conditions, rabbits have higher serum $\mathrm{Ca}$ levels than other mammals. Serum Ca level is not affected by factors such as age and sex. Whereas presented in Table 1 the $\mathrm{Ca}$ and $\mathrm{P}$ levels were higher than the previous studies $(16,22)$, these parameters of our study were parallel to another results $(14,15)$.

In conclusion, our study suggested that determining the normal values of serum biochemistry in New Zealand white rabbits may be beneficial to both clinicians and researchers. On the other side, both the clinical evaluation and to determining health status of animals should be tested at regular intervals and should be based on the values of the control group in the same conditions. 


\section{REFERENCES}

1. Yanni AE. The laboratory rabbit: an animal model of atherosclerosis research. Lab Anim, 2004; 38(3): 246-56.

2. Calasans-Maia MD, Monteiro ML, Ascoli FO, Granjeiro $J M$. The rabbit as an animal model for experimental surgery. Acta Cir Bras, 2009; 24(4): 325-8.

3. Wang W, Xu R, Li J. Production of Native Bispecific Antibodies in Rabbits. PLoS ONE, 2010; 5(6):e10879. doi:10.1371/journal.pone.001087.

4. Matsuzawa T, Nomura M, Unno T. Clinical pathology reference ranges of laboratory animals. $\mathrm{J}$ Vet Med Sci, 1993; 55: 351-62.

5. Mohri M, Sharifi K, Eidi S. Hematology and serum biochemistry of Holstein dairy calves: age related changes and comparison with blood composition in adults. Res Vet Sci, 2007; 83: 30-39.

6. Olayemi FO, Nottidge HO. Effect of age on the blood profiles of the New Zealand White rabbit in Nigeria. Afr J Biomed Res, 2007; 10: 73-76.

7. Mizoguchi $\mathrm{Y}$, Matsuoka T, Mizuguchi H, Endoh $\mathrm{T}$, Kamata R, Fukuda K, Ishikawa T, Asano Y. Changes in blood parameters in New Zealand White rabbits during pregnancy. Lab Anim, 2010; 44(1): 33-9. doi: 10.1258/la.2009.008002.

8. Valdez-Garcia JE, Lozano-Ramirez JF, Zavala J. Adult white New Zealand rabbitas suitable model for corneal endothelial engineering. BMC Res Notes, 2015; 4(8): 28. doi: 10.1186/s13104-015-0995-1.

9. Melillo A. Rabbit Clinical Pathology. Journal of Exotic Pet Medicine, 2007; 16(3): 135-145.
10. Fuentes GC, Newgren J. Physiology and clinical pathology of laboratory New Zealand White rabbits housed individually and in groups. J Am Assoc Lab Anim Sci, 2008; 47(2): 35-38.

11. Özkan C, Kaya A, Akgül Y. Normal values of haematological and some biochemical parametersin serum and urine of New Zealand White rabbits. World Rabbit Sci, 2012; 20: 253-259, <https://doi. org/10.4995/wrs.2012.1229.

12. Sabah AH, Abd Al-Rahman, Dalal Abd Al-Sattar Asaad Baqey. Effect of the thermal changes onphysiological, biochemical and histological traits in pregnantand embryo of New Zealand White rabbits. Int J Adv Biol Res, 2016; 6(2): 313-327.

13. Okab AB, El-Banna SG, Koriem AA. Influence of environmental temperatures on some physiological and biochemical parameters of New-Zealand rabbit males. Slovak J Anim Sci, 2008; 41(1): 12 - 19.

14. Yazar E, Çöl R, Konyalıoğlu S, Birdane YO, Elmas $M$, Baș AL. Effects of vitamin $E$ and prednisolone on biochemical and haematological parameters in endotoxaemic New Zealand White Rabbits. B Vet I Pulawy, 2004; 48: 105-108.

15. Saad MS, Mohamed AM, Khalid H. Some haematobiochemical values in White New Zealand rabbits. J Agric Vet Sci, 2017; 10(7): 40-44 DOI: 10.9790/2380-1007014044.

16. Seyidoğlu N, Galip N, Sonat FA. Effect of yeast culture on growth performance, haematological and biochemical indices of New Zealand white rabbits. Uludag Univ J Fac Vet Med, 32(2): 11-17, 2013. 24. 
17. Dontas IA, Marinou KA, Iliopoulos D, Tsantila N, Agrogiannis G, Papalois A, Karatzas T. Changes of blood biochemistry in the rabbit animal model in atherosclerosis research; a time- or stresseffect. Lipids Health Dis, 2011; 14(10): 139. doi: 10.1186/1476-511X-10-139.

18. Lebas CF, Coudert P, Rouvier R, Rochambeau H. The Rabbit Husbandry, Health and Production. The Food and Agricultureal Organisation of the United Nations, Rome. Ceviri: Vatansever, H. Ankara: Kardelen Ofset. 2002.

19. Manning P, Ringler DH, Newcomer C. The biology of the laboratory rabbit. Academic Press, 1994:111344.
20. Caisey JD, King DJ. Clinical chemical values for some common laboratory animals. Clin Chem, 1980; 26: 1877-1879.

21. Loeb W. Clinical Biochemistry of Laboratory Rodents and Rabbits. In: Kaneko JJ, Harvey JW, Bruss ML (eds.). Clinical biochemistry of domestic animals. California: Academic Press. 1997: 845-855.

22. Gil AG, Silvan G, Illera M, Illera JC. The effects of anesthesia on the clinical chemistry of New Zealand White rabbits. Contemp Top, 2004; 43(3): 25-29. 